\title{
ANALYSIS OF FACTORS INFLUENCING FARMERS' HOUSEHOLD CONSUMPTION IN MALANG CITY, INDONESIA
}

\author{
Sugiyanto ${ }^{1}$, Lintar Brillian Pintakami ${ }^{2 *}$ \\ ${ }^{1}$ Agricultural Socio-Economic, Brawijaya University, Indonesia \\ ${ }^{2}$ Agribusiness, Balitar Islamic University, Indonesia \\ *corresponding author: lintar.brillian@gmail.com
}

\begin{abstract}
Food has become a primary human need that must be fulfilled before fulfilling other living needs such as clothing, housing, and education. The present study analyzes food consumption patterns and factors influencing it in the Malang District. The analysis is done by tabulating data and then analyzed using the calculation of energy consumption adequacy based on the DDP reference. To analyze the influencing factors carried out using multiple linear regression analysis. Sampling is done by simple random sampling method as many as 100 housewives. The results indicate that the food consumption patterns of households in the Malang District have not reached ideal numbers. Simultaneously the income variable, the number of family members, the age of the mother, the level of maternal education significantly influence the food consumption patterns of households in Malang District while partially the income and number of families have a significant effect on household food consumption patterns in Malang District City.
\end{abstract}

Keywords: Pattern of Food Consumption, Household, Malang Regency

http://dx.doi.org/10.21776/ub.agrise.2021.021.2.9

Received 6 March 2020

Accepted 29 April 2021

Available online 30 April 2021

\section{INTRODUCTION}

Food is the essential basic need for humans to sustain life (Hamid et al., 2013). As human beings, people need food to live and socialize. It is a fact that people continually need food to survive. Food has become a primary human need that has to be fulfilled before fulfilling other life needs such as clothing, housing, and education. The importance of food is also stated by (Presiden, 1996) Republic of Indonesia contained in Law (UU) No. 7 year 199, in article 1 paragraph 17 that stated food security is a condition of food fulfillment for households that is reflected in the availability of adequate food, both in quantity and quality, safe, equitable, and affordable. Furthermore, (Coleman-Jensen et al., 2014) in the journal article entitled Household Food Security, explained the substantial of food security for each individual. Food security is one of the requirements and is obtained by everyone to get adequate food and nutrients for a dynamic and healthy life.

The quality and quantity of food consumption by each individual affect the status of the food security index. According to (Munawar Albadri et al., 2019) each family has its unique consumption behavior to meet their needs for both primary and secondary needs in their household. To this end, consumption is always related to household activities and becomes one of the main concepts in macroeconomics that provide national income. Food availability in the household is one of the indicators of the success of food security in the household itself. The realization of food security at the household level is measured by the ability to obtain enough food quantities, quality, and variety to meet food and nutrition needs. Enough here means not

CITATION: Sugiyanto, Pintakami, L., B., (2021). Analysis of Factors Influencing Farmers' Household Consumption in

Malang City, Indonesia, Agricultural Socio-Economics Journal, 21(2), 155-164 DOI:

http://dx.doi.org/10.21776/ub.agrise.2021.021.2.9 
only rice but includes non-rice food derived from plants, livestock, and fish to meet the needs of carbohydrates, fats, proteins, vitamins, and minerals that are beneficial for the growth of human health (Mien \& Said, 2018).

The role of the agricultural sector in realizing food security has to be improved and expanded, not only in terms of production and supply but also in aspects of public consumption patterns. The role of the agricultural sector in realizing food security must be improved and expanded, not only in terms of production and supply but also aspects of public consumption patterns are very important to know. Those aspects need to be considered because agricultural products are the main food providers for the community. In line with this, the "Study of The Main Food Consumption Pattern of Gunung Sereng Village Community" proved that about $70 \%$ of villagers depend on agricultural products, one of which is corn as a staple food every day (Margareta $\&$ Purwidiani, 2014). Food consumption patterns between households can vary depending on food availability, socio-cultural, nutritional knowledge, economy, and environment. One of the most influential factors is the income factor. The high low income of a household can affect the household in choosing and determining the type of food of a good nutritional quality that is diverse and balanced. Therefore, the change of the factor will lead to a household's food consumption patterns. Malang city as a city with a heterogeneous population background, with various levels of income, employment, ethnicity, and religion must be having the potential. Therefore, I am interested to research household food consumption patterns and the influencing factors.

\section{RESEARCH METHODS}

The research setting is determined by the purposive sampling method, which is chosen by consideration of research objectives (Sugiyono, 2017). Malang has an area of $110.0566 \mathrm{~km} 2$ with a population of 789.348 people. The justification of the research setting relies on the characteristics of the location where it is an educational city with a heterogeneous population background. The sampling method is done by the Slovin method with the following equation:

$$
n=\frac{N}{1+N e^{2}}
$$

Where:

1: constants

\author{
n: sample size \\ $\mathrm{N}$ : population size \\ E: percent of inaccuracy allowance due to \\ sampling errors can still be tolerated or \\ desired
}

With a total household population of 41.843 households and a tolerance error limit of $10 \%$, the calculation result obtained the number of samples as many as 99, 76, or 100 people. I used accidental sampling to select the participants in the present study in which the participant is determined by chance or people that are considered suitable as the source of data. The data used in this study consists of primary data and secondary data. Primary data were food consumption data that were collected through interviews and observation. The observation was directly administered in the research setting.

To answer the first research problem, I conducted a qualitative approach from observation of household food consumption patterns. The analysis covered the results of the interview and questionnaire. Then the interview results were presented in data tabulation and analyzed using the calculation of energy consumption adequacy based on Desirable Dietary Pattern (DDP) (Nugraheni, 2016) with the following formula:

1. Actual individual consumption $={ }^{\frac{B B A k A K G}{B B A K a l}} \times A K G$ Energi

2. Actual energy $=\left[B_{i} \times K E_{i} / \mathbf{1 0 0} \times\left(B D D_{i} / \mathbf{1 0 0}\right)\right] / J R T$

3. $\%$ Actual $=\frac{\text { Konsumsi Energi }}{\text { Kecukpupan Energi }} x 100 \%$

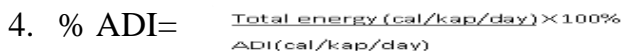

5. Weight is the determination of weights (Food Triguna)

6. Actual Score $=\%$ Actual $x$ Weight

7. ADI Score $=\%$ ADI $x$ Weight

8. DDP Score $=$ If the ADI score $>$ from the $\max$ score, then the max score used in the DDP score table and vice versa

\section{Weight Determination (Food Triguna) :}

1. Energy source (carbohydrate) $=33.33 \%$

2. Grains $(50 \%)$, tubers $(6 \%)$, oil and fat $(10 \%)$, oil $/$ seeds $(3 \%)$, sugar $(5 \%)$. Weight = $33.33 \% / 74 \%=0.5$.

3. Source builder $($ protein $)=33.33 \%$

4. Animal food (12\%), legumes $(5 \%)$. Weight $=$ $33.33 \% / 17 \%=2$.

2. Regulatory sources (vitamins and minerals) = $33.33 \%$ 
5. Vegetables and fruits (6\%). Weight = $33.33 \% / 6 \%=5$.

3. Others $(0.1 \%)$

6. Spices and beverages

7. $(3 \%)$. Weight $=0.1 \% / 3 \%=0.03$

8. Ideal DDP Score

9. $\mu=$ error term (coefficient of error)

\section{RESULTS AND DISCUSSION}

\section{General Condition of Malang City}

Malang is the second-largest city in East Java located at an altitude between 440-667 meters above sea level and at coordinates $112^{\circ} 34^{\prime} 13^{\prime \prime}-112^{\circ} 41$ '39" East Longitude and 7०54'40'- $8^{\circ} 3^{\prime} 5^{\prime \prime}$ South Latitude. Administratively, Malang is divided into 5 (five) sub-districts and 57 sub-districts. The five sub-districts include Kedungkandang, Klojen, Blimibing, Lowokwaru, and Sukun sub-districts. The area of Malang reaches 11.005,66 ha. The largest land allocation is used for the most extensive housing (42.59\%), dryland farming (24.19\%), and rice fields $(21.38 \%)$. The number of residents in Malang based on the results of population registration at the end of 2017 reached 789,348 people, each of the highest population density achieved consecutively by the districts of Blimbing, Klojen, Kedungkandang, Sukun, and Lowokwaru, namely: 9,$298 ; 14,360 ; 3,768 ; 7,182$ and 7,044 inhabitants $/ \mathrm{km} 2$. According to the results of the 2,000 population census, the population growth level in Malang reached $0.86 \%$ per year. The population density in Malang reaches 6,906 inhabitants $/ \mathrm{km} 2$ where the highest density is in the Klojen sub-district of 14,360 inhabitants $/ \mathrm{km} 2$.

The trade sector becomes the major livelihood, especially small and medium-sized businesses that play an important role in the economy in Malang. While the number of people working in the agricultural sector turned out to show a relatively small number, which reached 13,190 or $4.00 \%$ of the total existing workforce. This can be understood because the agricultural land in Malang is relatively limited. The condition of the encouraging pace of economic growth in Malang has not been balanced with the relatively uneven distribution of people's income, where only about $11.11 \%$ of the people of Malang have expenditures above Rp500,000/month and $1.72 \%$ are community groups with expenditures below Rp100,000/ month, while the rest are distributed at a level of expenditure between Rp100,000 to Rp500,000/month. For that reason, economic growth in Malang grows faster compared to other surrounding areas (BPS, 2017).

\section{Profile of Food Consumption Patterns in Malang}

Consumption patterns are various information that provides a description of the amount and type of food eaten daily by one person and have characteristics for a specific group of people (Tamawiwi, 2015). The household consumption pattern is an indicator of household/family welfare. Hitherto, there has been a growing understanding that the size of the proportion of spending on food consumption for all household expenditures can provide an overview of household well-being. The higher the household income level, the smaller the proportion of food expenditure for all household expenditures.

Identification of dietary consumption patterns is an important strategy to promote balanced nutrition and reduce disability associated with excess weight gain (Kayode \& Alabi, 2020). Besides according to (Khalid et al., 2017) information on dietary habits and food consumption is essential for developing nutrition programs to prevent and control food insecurity problems. The availability of food in an area affects the consumption patterns of local people. An area will use the natural resources obtained from its residential area to meet all the needs of its inhabitants (Margareta \& Purwidiani, 2014). People's food needs from one region to another have a variety of differences, including the farming community in Malang.

Overall, the number of DDP scores in Malang is 88.06 and is considered good even though it is not ideal. This DDP score shows that the food condition of the people in Malang is quite diverse and not focused on one foodstuff only. Although people's food consumption has varied, this figure has not been able to be said to be ideal because the ideal score of PPH is at 100 . This indicates that there must be some foodstuffs that are increased in consumption to be balanced. Certainly inseparable from the consumption patterns of society will change in the future and produce a different impact on energy consumption. Although previous literature came to conclusions such as behavioral changes can affect consumption patterns of both individuals and households. So the need for energyefficient behavior to be recommended as a wise policy option, the potential for energy conservation contained in the demand side has not been explicitly quantified so that the government cannot implement 
a more targeted demand-side regulatory policy (Ding et al., 2017).

Based on the current condition of DDP, it can be seen that vegetable and fruit groups, animal food, and grains are still the three most dominant food groups contributing to the DDP score. Even so, these three food groups still need to get strengthening to achieve ideal conditions.

Also, there are groups of foodstuffs such as sugar, fruit or oily seeds, and tubers that should be used more must increase DDP scores. Regardless of this fact, nuts need to be attentively increased by the people. Consumption of these foodstuffs is above the ideal score but should be increased consumption in other foodstuffs that are less than ideal to be balanced.

All in all, out of the nine food categories consumed by the community in Malang, two categories have been fulfilled. Public consumption is only fulfilled for fruit or oily seeds and nuts categories, while seven other categories still cannot be fulfilled.

Table 1. Malang DDP Calculation Result

\begin{tabular}{|c|c|c|c|c|c|c|c|}
\hline \multirow{2}{*}{ No } & \multirow{2}{*}{$\begin{array}{l}\text { Food } \\
\text { Categories }\end{array}$} & \multicolumn{6}{|c|}{ DDP Calculation } \\
\hline & & Cal & $\begin{array}{c}\% \\
\text { ADI } \\
\end{array}$ & Weight & $\begin{array}{c}\text { ADI } \\
\text { Score }\end{array}$ & $\begin{array}{l}\text { Max. } \\
\text { Score }\end{array}$ & $\begin{array}{l}\text { DDP } \\
\text { Score }\end{array}$ \\
\hline 1. & & & & & & & \\
\hline 2. & Grains & 961.46 & 44.72 & 0.50 & 22.36 & 25.00 & 22.36 \\
\hline 3. & Tubers & 51.08 & 2.38 & 0.50 & 1.19 & 2.50 & 1.19 \\
\hline 4. & Meats & 217.53 & 10.12 & 2.00 & 20.24 & 24.00 & 20.24 \\
\hline 5 & Oils and Fats & 191.60 & 8.91 & 0.50 & 4.46 & 5.00 & 4.46 \\
\hline 6. & & 73.04 & 3.40 & 0.50 & 1.70 & 1.00 & 1.00 \\
\hline 7. & Nuts & 218.88 & 10.18 & 2.00 & 20.36 & 10.00 & 10.00 \\
\hline & Sugar & 36.22 & 1.68 & 0.50 & 0.84 & 2.50 & 0.84 \\
\hline 8. & $\begin{array}{l}\text { Fruits and } \\
\text { vegetables }\end{array}$ & 120.32 & 5.60 & 5.00 & 27.98 & 30.00 & 27.98 \\
\hline & Others & 26.14 & 1.22 & 0.00 & 0.00 & 0.00 & 0.00 \\
\hline & Total & $\begin{array}{r}1,896 . \\
29 \\
\end{array}$ & & & 99.12 & 100.00 & 88.06 \\
\hline
\end{tabular}

Source: Primary Data, Processed (2019)

\section{Analysis of Factors Affecting Farmers' Household Consumption in Malang City \\ a. Analysis of Energy Consumption}

The hypothesis tested in this study is the level of household energy consumption of three types of agro-ecology is influenced by farming experience (X1), knowledge on nutrition (X2), expenditure for food (X3), household income (X4), formal education (X5), farmer age (X6), diversification of food consumption (X7), frequency of eating (X8) and the number of families (X9). The data was analyzed using SPSS Version 15 with a $5 \%$ and $1 \%$ level of significance. Before conducting hypothetical tests, correlation analysis is first conducted to measure the correlation between variables. The inter-variable correlation analysis was computed with Bivariate Correlation Analysis using Pearson Correlation Analysis and Multicolinearis Test.

The Multicollinearity test to measure the regression model found in the correlation between independent variables. The best regression model is found when no correlation exists in independent variables. However, if they correlate with each other, it implies that they have non-Orthogonal properties. An orthogonal variable is an independent variable whose correlation value between independent variables equals zero. Moreover, the Multicollinearity in the regression model is determined by tolerance value and Variance Infiltration Factor (VIF).

In this study, independent variables had no multicolinearity. It is proven by obtaining a tolerance value for all independent variables $<0.10$ or equal to VIF $<10$. The score entails farming experience $(\mathrm{X} 1)=1,446$, knowledge of nutrition $(X 2)=2,217$, food expenditure $(X 3)=2,370$, household income $(\mathrm{X} 4)=1,817$, formal education level $(\mathrm{X} 5)=1,069$, age $(\mathrm{X} 6)=1,270$, diversification of food consumption $(X 7)=2,067$, frequency of eating $(\mathrm{X} 8)=1,116$, and number of families $(\mathrm{X} 9)=$ 1,608 . The result of are presented in the following table.

Table 2. Effect of Independent Variables on Energy Consumption Rate

\begin{tabular}{|c|c|c|c|c|}
\hline No & $\begin{array}{l}\text { Dependent } \\
\text { Variable } \\
(\mathbf{Y})\end{array}$ & $\begin{array}{l}\text { Independent } \\
\text { Variable (X) }\end{array}$ & $\begin{array}{c}\text { Regression } \\
\text { Coefficient (b) }\end{array}$ & $\begin{array}{l}\text { Level of } \\
\text { Sig. }\end{array}$ \\
\hline 1 & \multirow{10}{*}{$\begin{array}{l}\text { Energy } \\
\text { consumption } \\
\text { level }\end{array}$} & Constant (a) & 0,19 & 0,925 \\
\hline 2 & & $\begin{array}{l}\text { Farming } \\
\text { experience (X1) }\end{array}$ & 0,001 & 0,755 \\
\hline 3 & & $\begin{array}{l}\text { Knowledge on } \\
\text { nutrition (X2) }\end{array}$ & 0,425 & $0,000^{\text {** }}$ \\
\hline 4 & & $\begin{array}{l}\text { Expenditure for } \\
\text { food (X3) }\end{array}$ & 0,461 & $0,000 * *$ \\
\hline 5 & & $\begin{array}{l}\text { Household } \\
\text { income (X4) }\end{array}$ & 0,045 & 0,194 \\
\hline 6 & & $\begin{array}{l}\text { Formal education } \\
\text { (X5) }\end{array}$ & $-0,006$ & 0,424 \\
\hline 7 & & Age (X6) & 0,009 & 0,873 \\
\hline 8 & & $\begin{array}{l}\text { Diversification } \\
\text { of food } \\
\text { consumption } \\
\text { (X7) }\end{array}$ & 0,080 & $0,030^{* *}$ \\
\hline 9 & & $\begin{array}{l}\text { Frequency of } \\
\text { eating (X8) }\end{array}$ & 0,045 & 0,459 \\
\hline 10 & & $\begin{array}{l}\text { Number of } \\
\text { families (X9) }\end{array}$ & $-0,047$ & 0,170 \\
\hline & F hit & 125,155 & & 0 \\
\hline & R Square & & & 0,86 \\
\hline
\end{tabular}

Source: Primary Data, Processed (2019)

Based on the table above, multiple regression equations are obtained, between energy consumption level (Y1) with farming experience 
(X1), knowledge on nutrition (X2), food expenditure (X3), household income (X4), formal education (X5), farmer age (X6), diversification of food consumption (X7), frequency of eating (X8) and the number of families (X9) as follows. Obtained Multiple Regression Model Testing simultaneously with F count 125, 155, while F Table 5\% (db 198.9) $=8.84$ and $\mathrm{F}$ Table $1 \%(\mathrm{db} 198 ; 9)=27.49$, and obtained the best Guessing Model as follows.

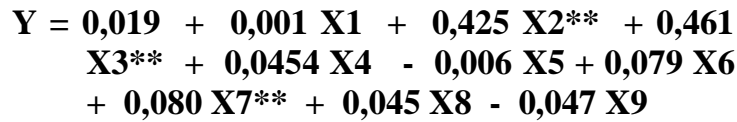

Description: :

$\mathrm{Y}$ = Energy consumption level

$\mathrm{X} 1$ = Farming experience

$\mathrm{X} 2=$ Knowledge of Nutrition

$\mathrm{X} 3$ = Expenditure for food

$\mathrm{X} 4$ = Household income

$\mathrm{X} 5=$ Formal education

$\mathrm{X} 6=$ Age

$\mathrm{X} 7=$ Diversification of food consumption

$\mathrm{X} 8=$ Frequency of eating

$\mathrm{X} 9=$ Number of families

$\mathrm{R} 2=0,86$

The result of the multiple regression is $R$ Squared $=0.86$. This means that household energy consumption level, influenced jointly by farming experience (X1), knowledge about nutrition (X2), food expenditure (X3), Household income (X4), a formal education level (X5), age (X6), diversification of food consumption (X7), frequency of eating (X8), and the number of families (X9) by $86 \%$, the remaining $14.0 \%$ is influenced by other factors that are not incorporated in the model.

Reflecting upon the result, it depicts that $\mathrm{F}$ Change of $0.000(<0.05)$. It implies that simultaneously variable energy consumption level is significantly influenced by farming experience (X1), knowledge on nutrition (X2), expenditure for food (X3), household income (X4), a formal education level (X5), age (X6), Diversification of food consumption (X7), frequency of eating (X8), and the number of families (X9). The regression coefficient values of each independent variable are as follows.

a. The regression coefficient of farming experience (X1) is 0.001 with a level of significance of 0.755 . The magnitude of the significance value is > 0.005 ; thus, it can be interpreted that farming experience has no significant contribution to the level of energy consumption of farmers' households.

b. The regression coefficient of knowledge on nutrition (X2) is 0.0425 with a level of significance of 0.000 . The magnitude of the significant value is $<0.005$. Thus it can be said that Knowledge of nutrition has a significant contribution to the level of energy consumption of farmers' households.

c. The regression coefficient of expenditure for food (X3) is 0.461 with a level of significance of 0.00 . The magnitude of the significance value is $<0.05$; thus it can be said that food expenditure has a significant contribution to the level of energy consumption of farmers' households.

d. The regression coefficient of household income (X4) is 0.045 with a level of significance of 0.194 . The magnitude of the significance value is $>0.005$; thus, it can be interpreted that the household income level does not have a significant contribution to the level of energy consumption of farmers' households.

e. The regression coefficient of formal education level (X5) is 0.006 with a level of significance of 0.424 . The magnitude of significant value is $<0.005$; thus it can be said that knowledge on nutrition has no significant contribution to the level of energy consumption of farmers' households.

f. The regression coefficient of age (X6) is 0.009 with a level of significant 0.87 . The magnitude of the significance value is > 0.05 ; thus it can be said that age has no significant contribution to the level of energy consumption of farmers' households.

g. The regression coefficient of food consumption diversification (X7) is 0.080 with a level of significance of 0.030 . The magnitude of the significance value is < 0.05 ; thus it can be said that the diversification of food consumption has a significant contribution to the level of energy consumption of farmers' households.

h. The regression coefficient of frequency of eating (X8) is 0.045 with a level of significance of 0.459 . The magnitude of the significance value is $>0.005$; thus, it can be interpreted that the frequency of eating does not have a significant contribution to the level of energy consumption of farmers' households.

i. The regression coefficient (X9) is -0.047 with a level of significance of 0.170 . The magnitude of the significant value is > 0.005 ; thus it can be said that the number of families has no significant contribution to the level of energy consumption of 
farmers' households. A negative sign means that the more family members, the more likely the level of energy consumption of farmers' households.

Based on the aforementioned interpretation, it can be concluded that the significant factors contributing to the level of energy consumption in farmers' households in Malang are knowledge on nutrition, food expenditure, and diversification of food consumption. Based upon the information, the recommended strategy is increasing knowledge about nutrition and family financial management.

Education on nutrition with an emphasis on vegetable consumption is recommended especially consuming a diet high in vegetables associated with a low Body Mass Index (Kayode \& Alabi, 2020). The increasing westernization, urbanization, and mechanization occurring in most surrounding countries of the world are associated with changes in diet towards one of the foods high in fat, high energy solids, and sedentary lifestyles. This shift is also linked to current rapid changes in children and adult obesity. Even in many low-income countries, obesity is now rising rapidly, and often coexisting in the same population as chronic malnutrition. The transition of nutrients in developing countries leads to the intake of foods poor in micronutrients, energydense, which may be an important determinant of overweight or obesity and essential for children's development.

\section{b. Analysis of Protein Consumption}

The hypothesis tested in this study is the farmers' household protein consumption of agroecological areas is influenced by farming experience (X1), knowledge on nutrition (X2), expenditure for food (X3), household income (X4), formal education (X5), farmer age (X6), diversification of food consumption (X7), frequency of eating (X8) and the number of families (X9). The data was computed in SPSS Program Version 15. The result of the computation is presented in the table as follows.

Table 3. Effect of Independent Variables on Protein Consumption

\begin{tabular}{llccccc}
\hline No & Model & $\begin{array}{c}\text { Sum } \\
\text { Squared } \\
(\text { SS })\end{array}$ & df & $\begin{array}{c}\text { Middle } \\
\text { Squared } \\
\text { (MS) }\end{array}$ & F hit & $\begin{array}{c}\text { F tab } \\
\mathbf{5 \%}\end{array}$ \\
\hline 1 & Regression & 35.385 & 9 & 3.984 & 76,727 &, 00 \\
2 & Residual & 9.813 & 189 & 0,052 & & \\
3 & Total & 45.668 & 198 & & & \\
\hline
\end{tabular}

Source: Primary Data, processed (2017)
Description

1. Independent variables: frequency of eating, formal education, diversification of food consumption, age, farming experience, number of families, knowledge on nutrition, household income, and food expenditure.

2. Dependent variable: Household Protein Consumption Level.

The following is the equations from the Multiple Regression Analysis:

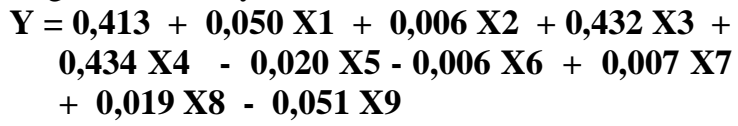

Description:

$\mathrm{Y}=$ Household protein consumption

$\mathrm{X} 1=$ Number of families

$\mathrm{X} 2$ = Farming experience

$\mathrm{X} 3=$ Knowledge of nutrition

$\mathrm{X} 4$ = Expenditure for food

X5 = Household income

$\mathrm{X} 6=$ Formal education

$\mathrm{X} 7=$ Age

$\mathrm{X} 8=$ Diversification of food consumption

$\mathrm{X} 9=$ Frequency of Eating

$\mathrm{R} 2=0.785$

Using Variant Analysis, it is revealed that the significance value is $0.0001(<0.005)$ which means variable Protein Consumption Rate, simultaneously and significantly influenced by family number variable (X1), farming experience (X2), knowledge of nutrition (X3), food expenditure (X4), household income (X5), a formal education level (X6), age (X7), diversification of food consumption (X8), and frequency of eating (X9).

Based on the result, the equation above obtained from R squared is 0.785 or $78.5 \%$. The result implies that the level of household protein consumption in Malang is influenced jointly by the variable farming experience (X1), knowledge on nutrition (X2), food expenditure (X3), household income (X4), formal education (X5), farmer age (X6), diversification of food consumption (X7), frequency of eating (X8) and the number of families (X9). The rest is influenced by the presence of other factors that are not studied. After further analysis, it turned out that the protein consumption level, strongly influenced by many factors, mainly influenced the overall of the independent variables analyzed. 
Table 4. Effect of Independent Variables on Protein Consumption

\begin{tabular}{|c|c|c|c|c|c|}
\hline No & $\begin{array}{c}\text { Dependent } \\
\text { Variable (Y) }\end{array}$ & $\begin{array}{l}\text { Independent } \\
\text { Variable } \\
\text { (X) }\end{array}$ & $\begin{array}{l}\text { Regression } \\
\text { Coefficient } \\
\text { (b) }\end{array}$ & $\begin{array}{c}\text { Level of } \\
\text { Significance }\end{array}$ & Description \\
\hline 1 & \multirow{10}{*}{$\begin{array}{l}\text { Protein } \\
\text { consumption } \\
\text { level }\end{array}$} & Constant (a) & 0.413 & 0.925 & - \\
\hline 2 & & $\begin{array}{l}\text { Farming } \\
\text { experience } \\
\text { (X1) }\end{array}$ & 0.50 & 0.002 & $*$ \\
\hline 3 & & $\begin{array}{l}\text { Knowledge of } \\
\text { nutrition (X2) }\end{array}$ & 0.006 & 0.180 & $*$ \\
\hline 4 & & $\begin{array}{l}\text { Expenditure } \\
\text { for food (X3) }\end{array}$ & 0.432 & 0.432 & $*$ \\
\hline 5 & & $\begin{array}{l}\text { Household } \\
\text { income (X4) }\end{array}$ & 0.434 & 0.434 & - \\
\hline 6 & & $\begin{array}{l}\text { Formal } \\
\text { education } \\
\text { (X5) }\end{array}$ & -0.020 & 0.655 & - \\
\hline 7 & & Age (X6) & -0.006 & 0.543 & - \\
\hline 8 & & $\begin{array}{l}\text { Diversificatio } \\
\mathrm{n} \text { of food } \\
\text { consumption } \\
\text { (X7) }\end{array}$ & 0.007 & 0.681 & - \\
\hline 9 & & $\begin{array}{l}\text { Frequency of } \\
\text { eating (X8) }\end{array}$ & 0.019 & 0.681 & - \\
\hline 10 & & $\begin{array}{l}\text { Number of } \\
\text { families (X9) }\end{array}$ & -0.051 & 0.508 & - \\
\hline & $\begin{array}{l}\text { F hit } \\
\text { R Square }\end{array}$ & 125.155 & & 0 & $\begin{array}{c}* * \\
0.86(86 \%) \\
\end{array}$ \\
\hline
\end{tabular}

The detailed interpretation for each independent regression coefficient value variable is as follows:

a. The regression coefficient of the number of families $(\mathrm{X} 1)$ is -0.050 with a significance level of 0.002 . The magnitude of the significance value is $<0.05$; thus it can be interpreted that the number of families has a significant contribution to the level of farmers' household protein consumption.

b. The regression coefficient of farming experience (X2) is 0.006 with a significance level of 0.180 . The magnitude of significant value $>0.05$; thus it can be understood that Farming Experience has a significant contribution on the level of farmers' household protein consumption.

c. The regression coefficient of knowledge on nutrition (X3) is 0.0432 with a significance level of 0.00 . The magnitude of the significance value is $<0.05$; thus it can be highlighted that Knowledge of Nutrition has a significant contribution to the level of farmers' household protein consumption.

d. The regression coefficient of expenditure for food (X4) is 0.434 with a significance level of 0.655 . The magnitude of the significance value is $>0.05$; thus, it can be interpreted that expenditure for food does not significantly contribute to the level of farmers' household protein consumption.

e. The regression coefficient of household income (X5) is 0.020 with a significance level of 0.424 . The magnitude of significant value $<0.05$; thus it can be said that household income has no significant contribution to the level of farmers' household protein consumption. f. The regression coefficient of formal education level (X6) is 0.006 with a significance level of 0.543 . The magnitude of the significance value is $>0.05$; thus it can be said that the formal education level has no significant contribution to the level of farmers' household protein consumption.

g. The regression coefficient of age (X7) is 0.080 with a significance level of 0.681 . The magnitude of the significance is > 0.05 ; thus it can be said that age has no significant contribution to the level of farmers' household protein consumption.

h. The regression coefficient diversification of food consumption (X8) is 0.080 with a significance level of 0.681 . The magnitude of the significance value is $>0.005$; thus, it can be interpreted that the diversification of food consumption does not have a significant contribution to the level of farmers' household protein consumption.

i. The regression of eating frequency (X9) is 0.045 with a significance level of 0.508 . The magnitude of the significant value is > 0.05 ; thus it can be said that the frequency of eating has no significant contribution to the level of farmers' household protein consumption. A negative sign means that the more family members, the more likely the level of household protein consumption of farmers.

Based on the results of the double regression analyses, it can be concluded that in Malang the protein consumption level in the household is influenced by some significant variables, namely the number of families, knowledge on nutrition, and age. Food consumption is information about the type and amount of food consumed by a person or group of people at a certain time while the level of consumption is a comparison of nutrients consumed with the recommended adequacy. The level of consumption of nutrients directly affects a person's nutritional status; in addition to health history also affects the nutritional status. However, in this study, the history of health is a variable that is not observed.

From the results of multiple regression analysis obtained significant factors affecting the level of protein consumption in households in Malang are knowledge on nutrition, food expenditure, and how to obtain food. Based on the results of the analysis that has been done, the recommended strategy is to increase knowledge about nutrition through training on the processing of nutritious meaning and management of family finances. 


\section{CONCLUSION}

All in all, the results of the present study can be concluded in the following points:

1. Overall, the DDP score in Malang is 88.06 and is considered good even though it is not ideal. This DDP score shows that the food condition of the people in Malang is quite diverse and not focused on one food category.

2. Based on the current condition of DDP, the group of vegetables and fruits, animal food, and grains are still the three most dominant food groups contributing to the acquisition of the DDP score. Even so, these three food groups still need to get strengthening to achieve ideal conditions.

3. The pattern of household food consumption in Malang District has not reached the ideal figure of 80.25. Besides, the food consumption pattern in Malang District is dominated by grain groups, then followed by meats, vegetables and fruits, nuts, oils and fats, sugars, others, tubers, and oily fruits or seeds.

4. Simultaneously, the four factors (household income, number of family members, age of housewives, and maternal education level) have a significant contribution to household food consumption patterns. Partially, the income factor and the number of family members have a significant effect on household food consumption patterns. Moreover, the maternal age factor and the level of maternal education have no significant contribution to household food consumption patterns.

\section{SUGGESTIONS}

Reflecting upon the results, some suggestions are made and addressed to some parties as stated as follows:

1. It is suggested that Malangese people should pay more attention to the pattern of food consumption to have more diverse and balanced food consumption. This is suggested to achieve food consumption patterns following the ideal standards expected.

2. The local government should provide socialization on the importance of fulfillment of diverse and balanced food nutrition. This is expected to improve the welfare of the community in terms of actual food consumption levels and the achievement of the Food Hope Pattern (PPH) score.

3. The researchers are also expected to be able to examine the picture of actual household food consumption in other areas, compare food consumption patterns between villages and cities, examine the picture of food consumption patterns among several ethnicities, and analyze factors other than the above factors to see the effect on actual household food consumption.

4. Diversification of food consumption is done by creating new jobs that are an alternative because the results of the study show that the more food sources purchased the better energy and protein consumption. Therefore efforts are needed to increase the income of the population in Malang City.

5. The numbers of families need to be managed by intensifying the Family Planning (KB) program because lately the program has been weakening.

\section{ACKNOWLEDGEMENTS}

Author would like to thank profusely to: Government, in this case the Ministry of National Education (DIKTI) and Thank you to Malang Brawijaya University, which has provided an opportunity for the author to get Research Grant Program For Professors And Doctors.

\section{REFERENCES}

BPS. (2017). Malang Dalam Angka. In Badan Pusat Statistik Malang (p. 191). BPS Malang.

Coleman-Jensen, A., Gregory, C., \& Singh, A. (2014). Economic Research Service Economic Research Report Number 173 Household Food Security in the United States in 2013. United States Department of Agriculture Economic, September.

Ding, Q., Cai, W., Wang, C., \& Sanwal, M. (2017). The relationships between household consumption activities and energy consumption in china- An input-output analysis from the lifestyle perspective. Applied Energy, 207, 520-532. https://doi.org/10.1016/j.apenergy.2017.06.00 3

Hamid, Y., Setiawan, B., \& Suhartini, S. (2013). Analisis Pola Konsumsi Pangan Rumah Tangga. AGRISE, XIII(3), 1412-1425.

Kayode, O. O., \& Alabi, Q. K. (2020). Food consumption patterns, physical activity, and overweight and obesity among undergraduates of a private university in Nigeria. Clinical Nutrition Experimental, 31, 28-34. https://doi.org/10.1016/j.yclnex.2020.01.001

Khalid, F. A., Ali, A. K. M., Ali, S. A., Mosmar, Z. Y. A., Salih, S. S. M., Salman, T. K., Desogi, M. A., Soghaier, M. A., Mohammed, E. E., \& Mohammed, A. A. (2017). Households' dietary habits and food consumption patterns in Hamishkoreib locality, Kassala State, 
Sudan. Journal of Ethnic Foods, 4(3), 181186. https://doi.org/10.1016/j.jef.2017.08.009

Margareta, D., \& Purwidiani, N. (2014). Kajian Tentang Pola Konsumsi Makanan Utama Masyarakat Desa Gunung Sereng Kecamatan Kwanyar Kabupaten Bangkalan Madura. EJournal Boga, 03(3), 86-95.

Mien, T. S., \& Said, R. (2018). A cross-sectional household analysis of household consumption patterns: An indirect approach to identify the possible factors of personal bankruptcy. Jurnal Ekonomi Malaysia, 52(3), 245-261. https://doi.org/10.17576/JEM-2018-5203-18

Munawar Albadri, A. A., Permana, I. S., \& Alfarisi, M. J. (2019). Factors Affecting Muslim Household Consumption Patterns. SSRN Electronic Journal, August. https://doi.org/10.2139/ssrn.3445315
Nugraheni, M. (2016). Pedoman analisis konsumsi pangan.

Presiden. (1996). Undang Undang No . 7 Tahun 1996 Tentang: Pangan. Jurnal Sosial Humaniora, 8(2), 4. https://doi.org/10.12962/j24433527.v8i2.1251

Sugiyono. (2017). Metode Penelitian Pendidikan Pendekatan Kuantitatif, Kualitatif, dan R \& D (23rd ed.). Alfabeta.

Tamawiwi, K. N. (2015). Pola Konsumsi Masyarakat Miskin Desa Tiwoho Kecamatan Wori Kabupaten Minahasa Utara. https://ejournal.unsrat.ac.id/index.php/cocos/a rticle/viewFile/8204/7763https://ejournal.unsr at.ac.id/index.php/cocos/article/viewFile/8204 17763 
This page is intentionally left blank 